\title{
VI. IN MEMORIAM
}

\section{PROFESOR WIESLAW KOZUB-CIEMBRONIEWICZ (1944-2015)}

W dniu 13 lutego 2015 r. zmarł po długiej chorobie Wiesław Kozub-Ciembroniewicz, profesor zwyczajny Uniwersytetu Jagiellońskiego, twórca i pierwszy dziekan Wydziału Stosunków Międzynarodowych i Politycznych UJ, prawnik, politolog, historyk-humanista, wybitny badacz, ceniony nauczyciel akademicki, wychowawca licznych zastępów młodzieży naukowej, niezrównany organizator życia naukowego, działacz społeczny. Był wspaniałym człowiekiem; potrafił cieszyć się darami życia, zarażać optymizmem otoczenie, ale i wymagającym wobec otoczenia i siebie. Nieubłagana śmierć zabrała Go przedwcześnie, w trakcie realizowania rozległych planów na wielu polach. Będzie Go brakowało przyjaciołom, uczniom, środowisku, Uniwersytetowi.

Wiesław Kozub-Ciembroniewicz przez całe życie związany był z Krakowem. Tu się urodził w 1944 r., tu zdobył wykształcenie średnie w ekskluzywnym Liceum im. Nowodworskiego; na Uniwersytecie kończył studia, wpierw prawnicze, potem historyczne na Wydziale Filozoficzno-Historycznym. Już w 1967 r. został zatrudniony w Katedrze Historii Doktryn Politycznych i Prawnych na Wydziale Prawa i Administracji UJ, kierowanej przez Konstantego Grzybowskiego, a po jego tragicznej śmierci w 1970 r. - przez Marka Sobolewskiego. Doktorat obronił rozprawą pt. Państwo faszystowskie Mussoliniego. Doktryna polityczna i regulacje prawne. W 1974 r. uzyskał stopień doktora habilitowanego w oparciu o rozprawę Socjaldemokracja w Austrii współczesnej 1945-1966. Tytuł profesora nadzwyczajnego uzyskał w 1993 r., tytuł profesora zwyczajnego - w 2008 r.

Profesor Wiesław Kozub-Ciembroniewicz pozostawił po sobie bogaty dorobek twórczy. Najważniejszym i najbardziej rozległym polem Jego badawczych fascynacji były ustroje i idee państw niedemokratycznych XX stulecia. Szedł tu śladem swoich mistrzów, którymi - poza Konstantym Grzybowskim i Markiem Sobolewskim - byli także Karol Jonca i Franciszek Ryszka. Wiele skorzystał z uczestnictwa w seminarium Juliusza Bardacha. W Krakowie 
i Wrocławiu uczył się historii autorytaryzmu, w Warszawie zdobywał wiedzę o tym, jako z autorytaryzmem i faszyzmem walczono. Nie był metodologiem nauk o przeszłości, ale pociągała go owa immanentna więź, istniejąca między strukturami a światem idei. Szukał tych powiązań; unikał prostych definicji. Był jednym z pierwszych polskich badaczy, którzy badali i ustrój, i doktryny; należał też do tych, którzy autorytaryzmu nie identyfikowali z faszyzmem. Miał zmysł pozwalający budować syntezy, ale zarazem solidne przygotowanie do egzegezy analitycznej. Syntetyczny wymiar posiadały jego monografie o dziejach państwa Mussoliniego. To przede wszystkim książki: Podstawy ideologiczne włoskiego faszyzmu (1977), Doktryny włoskiego faszyzmu i antyfaszyzmu 1922-1939 (1922), Doktryna i system władzy Włoch faszystowskich na tle porównawczym (2010). Mistrzostwo w operowaniu materiałem analitycznym demonstrował w małych formach pisarstwa. To rzetelne studia nad ludźmi totalitarnych Włoch. Przedmiotem jego badania byli m.in. Benedetto Croce, Luigi Sturzo, Filippo Turati (1986), Guido Bortolotto (1994), Sergio Panunzio (1996), Giovanni Gentile, Carlo Basille (1997), Alfredo Rococo (1999). Ich sylwetki, z reguły po raz pierwszy prezentowane polskiemu czytelnikowi, wciąż stanowią ewidentną wartość poznawczą. Sporo inwestował też Autor w poznanie trendów rozwoju w Niemczech. Pisał o Carlu Schmitcie; w 2000 r. ogłosił pionierską w literaturze książkę o Adenauerze (Konrad Adenauer. Personalizm i tradycjonalizm). Na początku swej drogi naukowej pasjonował się też życiem partyjnym w Austrii (Socjaldemokracja w Austrii wspólczesnej 1945-1960). Prezentował tę partię jako podmiot antykomunistyczny i antykonserwatywny, opisywał wpływ na jej program Karla Rennera i Karola Kautsky'ego. Do analiz nurtu chadeckiego na Zachodzie wracał niejednokrotnie. Podsumowaniem badań nad dyktaturami i tyranią była napisana wespół z Markiem Mankowiczem monografia Dyktatura i tyranie. Szkice niedemokratycznej władzy.

Drugim rozległym polem dociekań Wiesława Kozuba-Ciembroniewicza były dzieje prawicy w Polsce. Zajął się poglądami Antoniego Zygmunta Helcia, prekursora krakowskich stańczyków. Pamiętał też o swoim pierwszym naukowym mistrzu, Konstantym Grzybowskim, czy to publikując świetne szkice o nim jako historyku doktryn politycznych, czy to przypominając jego poglądy na faszyzm i narodowy socjalizm, czy wreszcie poświęcając mu obszerny tom pod własną redakcją (Konstanty Grzybowski - myśliciel sceptyczny). Recenzował prace innych polskich autorów, piszących na temat autorytaryzmu i faszyzmu. Zabierał głos życzliwie i zawsze kompetentnie w dyskusjach nad prawie wszystkimi książkami J. Borejszy, E. Cziomera. K. Joncy, M. Maciejewskiego H. Olszewskiego, F. Ryszki, M. Zmierczak.

Nie sposób wymienić wszystkie prace, które zawdzięczamy Wiesławowi Kozubowi- Ciembroniewiczowi. Pamiętamy wszelako o licznych Jego tekstach podręcznikowych, obejmujących myśl polityczną XIX i XX w., pisa- 
nych samodzielnie lub we współpracy z kolegami lub uczniami (Małgorzatą Kiwior-Filo, Joanną Sondel-Cedarmas, Joanną Stoker i innymi). Bibliografia Jego ważniejszych prac naukowych zawarta została w Księdze Pamiątkowej, wydanej przez środowiska badaczy krakowskich dla uczczenia czterdziestolecia pracy twórczej (Doktryny - historia - władza, pod red. Anny CitkowskiejKimli, Małgorzaty Kiwior-Filo oraz Bogdana Szlachty). Niejeden z autorów, piszących w tej Księdze, był uczniem Profesora. Wychował ich wielu i był bardzo z nich dumny.

Wiesław Kozub-Ciembroniewicz był autorem znanym i cenionym na Zachodzie. Współpracował z nauką niemiecką. Uczestniczył w ważnych konferencjach i był ich ,dobrym duchem”. Należał do władz Centrum Badań Holocaustu. Był wyróżniany i nagradzany. Uczestniczył w pracach renomowanych periodyków: „Politeji”, „Studiów nad Faszyzmem i zbrodniami hitlerowskimi” oraz „Czasopisma Prawno-Historycznego”. Należał do wyróżniających się członków krakowskiej palestry. Wiele pracy i serca wkładał w działania na rzecz piłkarskiego klubu Cracovia.

HENRYK OLSZEWSKI (Poznań)

\section{MIECZYSŁAW ŻOLNIERCZUK (1931-2016)}

W dniu 9 lutego 2016 r. zmarł w Rzeszowie w wieku prawie 85 lat emerytowany profesor UMCS, dr hab. Mieczysław Żołnierczuk, długoletni pracownik naukowo-dydaktyczny w Katedrze Prawa Rzymskiego Wydziału Prawa i Administracji UMCS w Lublinie, kierownik Zakładu Prawa Rzymskiego Filii UMCS w Rzeszowie, profesor Wyższej Szkoły Prawa i Administracji w Przemyślu i Rzeszowie.

Urodzony 29 maja $1931 \mathrm{r}$. w Zawalowie (powiat zamojski), po maturze wstąpił do seminarium duchownego, którego nie ukończył. W 1956 r. podjął studia prawnicze na Wydziale Prawa UMCS, zakończone dyplomem magistra prawa w 1961 r. Pracę magisterską na temat Odpłatne wyzwolenie niewolnika $w$ prawie rzymskim napisał na seminarium w Katedrze Prawa Rzymskiego pod kierunkiem ówczesnego docenta dra Adama Wilińskiego. Praca ta ukazała się później drukiem pt. Wykupienie się z niewoli w rzymskim prawie klasycznym (servus suis nummis emptus a pactum libertatis). Po ukończeniu studiów został zatrudniony na stanowisku asystenta w Katedrze Prawa Rzymskiego UMCS. Odbył również pozaetatową aplikację sądową, zakończoną egzaminem sędziowskim. Doktoryzował się w 1968 r., habilitował w zakre- 
sie prawa rzymskiego w r. 1978. Od 1 marca 1979 r. zajmował stanowisko docenta, które zachował po przejściu w 1981 r. do Filii UMCS w Rzeszowie; sprawował tam również kierownictwo Zakładu Prawa Rzymskiego. W latach 1981-1982 piastował ponadto funkcję Prorektora wymienionej Filii. W 1993 r. został powołany na stanowisko profesora nadzwyczajnego UMCS. Po przejściu na emeryturę w 2001 r. podjął pracę w Wyższej Szkole Prawa i Administracji w Przemyślu i Rzeszowie. W latach pracy zawodowej prowadził zajęcia z prawa rzymskiego, podstaw prawa cywilnego i rodzinnego oraz lektorat (konwersatorium) z języka łacińskiego dla prawników. Był bardzo cenionym dydaktykiem, znanym z wysokich wymagań egzaminacyjnych wobec studentów, ale też starannym i dbającym o właściwy poziom nauczania nauczycielem akademickim.

Rozprawa doktorska, od której zaczęła się Jego kariera naukowa romanisty, poświęcona była instytucji rzymskiego prokuratora - Falsus procurator w rozwoju historycznym instytucji prokuratora rzymskiego prawa prywatnego. Ten niełatwy i obszerny temat został zakończony gruntowną dysertacją i pomyślną obroną w dniu 6 października 1968 r. Promotorem był docent dr Adam Wiliński, recenzentami profesor dr hab. Kazimierz Kolańczyk i docent dr hab. Henryk Kupiszewski. Rozprawa ta została nagrodzona trzecią nagrodą w konkursie „Państwa i Prawa” na najlepsze prace doktorskie (1970 r.). Habilitował się na podstawie opublikowanej w Wydawnictwie UMCS rozprawy Rzymskie sadownictwo polubowne (okres przedklasyczny i klasyczny), którą przygotował, m.in. podczas półrocznego naukowego pobytu na rzymskim uniwersytecie La Sapienza. Kolokwium habilitacyjne odbyło się 28 czerwca 1978 r. na UMCS w Lublinie, recenzentami byli profesor dr hab. Cezary Kunderewicz, docent dr hab. Władysław Rozwadowski i docent dr hab. Marek Kuryłowicz. Za tę pracę uzyskał M. Żołnierczuk wyróżnienie w konkursie „Państwa i Prawa” (1979 r.). Poza wymienionymi pracami opublikował szereg artykułów, głównie z problematyki rzymskiego prokuratora. Były to: Falsus rocurator w rzymskim prawie klasycznym, Annales UMCS, 1969, vol. 16, sectio G, s. 85-121; Konstrukcja prawna prokuratora umocowanego w rzymskim prawie klasycznym, Annales UMCS, 1971, vol. 18, sectio G, s. 171-210; Rzymski prokurator umocowany (geneza i rodzaje w prawie klasycznym), Annales UMCS, 1975, vol. 22, sectio G, s. 163-191; Non verus procurator $w$ rzymskim prawie klasycznym, Annales UMCS, 1983, vol. 30, sectio G, s. 355-378; Falsus procurator w rzymskim prawie justyniańskim, Annales UMCS, 1985-1986, vol. 32-33, sectio G, s. 295-314). Odniósł się też do monografii P. Angeliniego, Il procurator (Milano 1971), publikując recenzję w CPH (1974, t. 26, z. 2, s. 241-248). Aktywność naukowa zaznaczyła się jeszcze dwoma artykułami dotyczącymi romanistycznej tradycji w prawie współczesnym (Rola prawa rzymskiego w ksztaltowaniu polskiego prawnika, Rzeszowskie Zeszyty Naukowe „Prawo - Ekonomia - Rolnictwo”, 1983, 
nr 1, s. 7-20 oraz: Elementi romanistici nel Codice civile della Repubblica Democratica Tedesco, „Index”, 1988, 16, s. 215-220). W sumie pozostawił po sobie wyspecjalizowany i niewątpliwie wartościowy dorobek naukowy w zakresie prawa rzymskiego. Publikacje odznaczały się rzetelnością badawczą i wnikliwą analizą tekstów źródłowych w dobrym stylu tradycyjnej romanistyki.

Po habilitacji skoncentrował się Profesor M. Żołnierczuk na pracy dydaktycznej i organizacyjnej, zwłaszcza w Filii UMCS w Rzeszowie. W 1980 r. ukazał się skrypt pt. Historia prawa państw antycznych (ze szczególnym uwzględnieniem prawa rzymskiego, we współpracy z J. Kosiorkiewicz i M. Kuryłowiczem, dostosowany do nowego programu studiów po tzw. reformie J. Baszkiewicza. Własny podręcznik wydał w 1992 r.: Zarys prawa rzymskiego. Skrypt dla studentów prawa Wydawnictwo Uniwersytetu Marii Curie-Skłodowskiej, 1992; drugie wydanie 1995; trzecie wydanie poprawione i rozszerzone 1998). Sprawował również opiekę naukową nad asystentami w Zakładzie Prawa Rzymskiego Filii UMCS w Rzeszowie, ale nie wypromował ostatecznie żadnego doktora.

W nekrologach pożegnano Zmarłego jako cenionego uczonego i nauczyciela akademickiego oraz doświadczonego dydaktyka. Dołącza się do tego niniejsze wspomnienie w imieniu osób, które zapamiętały życzliwie profesora Mieczysława Żołnierczuka z wieloletniej współpracy akademickiej.

MAREK KURYŁOWICZ (Lublin) 